Вісник ХНПУ імені Г.С. Сковороди. Психологія. Випуск 62.

https://doi.org/10.34142/23129387.2020.62.08

УДК 37.011

ORCID 0000-0001-6137-7686

\title{
ПСИХОФІЗІОЛОГІЧНІ ФАКТОРИ ТРАНСФОРМАЦЇ̈ ТРАВМАТИЧНОЇ ІНФОРМАЦІЇ У ПОСТТРАВМАТИЧНІ СТРЕСОВІ РОЗЛАДИ ТА ПСИХОЛОГІЧНОГО ЗАХИСТУ
}

\author{
Олександр О. Іллюк, \\ старший викладач кафедри сочіально-гуманітарних дисциплін, \\ Національна академія Національної гвардії України \\ E-mail: alalil1104@ukr.net
}

Актуальність дослідження. Невтішна статистика щодо суйидальної поведінки та скоєних злочинів учасниками операчії об'єднаних сил (антитерористичної операціï) на сході України актуалізують проблему наукових досліджень трансформаиіі постттравматичних стресових розладів (ПТСР).

Результати. Розглянуто методологічні основи співвідношення психіки і мозку та опису психофізіологічних прочесів щодо формування (послаблення, усунення) посттравматичних стресових розладів (ПТСР); наведено класифікацію психологічного захисту оптимізації, автоматизмів психологічного захисту $і$ травматичної інформацї̈; визначено можливі способи зберігання інформації про травматичні події в пам'яті; з'ясовано спосіб внутрішнього (фізіологічного) вираження психологічної травми у формі алгоритму травматичної конверсї та його роль у трансформачї негативної інформачії у ПТСР; розкрито залежність ефективності психологічного захисту оптимізачіi від способів зберігання травматичної інформачї у пам'яті; визначено співвідношення автоматизмів оптимізації $i$ adanmauiii.

Методологічною основою опису психофізіологічних факторів трансформачії травматичної інформачії в ПТСР є філософські положення про психіку людини, досягнення системного підходу в психології і фізіології, сучасні емпіричні теорії свідомості та інше.

Результати. Психотравмуюча подія може спричинити психічну травму. Внутрішнім (фізіологічним) проявом (вираженням) психічної травми є формування в керуючій (регулюючій) системі внутрішніх 
фізіологічних проиесів програми запуску $i$ відтворення алгоритму психофізіологічних процесів формування невротичних розладів. Зазначене психофізіологічне утворення пропонується позначати категорією «алгоритм травматичної конверсї̈. Алгоритм травматичної конверсї формується мимовільно під впливом цілісного відображення небезпечної подіï.

Алгоритм травматичної конверсії - це мимовільно сформована $i$ зафіксована в регулюючій системі фізіології організму програма запуску $i$ відтворення послідовних нейропсихофізіологічних прочесів щодо трансформації негативної інформачії в неприсмні пережсивання та постттравматичні стресові розлади.

Висновки. Основним напрямком (способом) пониження (усунення) негативних переживань $i$ ПТСР $\epsilon$ оптимізачія травматичної інформаиії, або їі сприйняття, наближено до інтересів особистості, через застосування психологічного захисту оптимізаиії.

$B$ основі несвідомого психологічного захисту оптимізачії $\epsilon$ автоматизми та архетипи оптимізації. Основним способом формування автоматизмів оптимізаиії с адаптація.

Наведено класифікацію інформації, щзо знаходиться $у$ несвідомій сфері психіки, та здатність окремих видів иієї інформації до оптимізаиіiі.

Можливість послаблення (усунення) ПТСР залежить від способів зберігання травматичної інформації в пам'яті.

При зберіганні негативної інформації лише в автобіографічній пам'яті у формі травматичних латентних мегабітів та кризисних фантомів - можливе повне усунення ПТСР.

При одночасному знаходженні травматичної інформації 6 автобіографічній пам'яті і в травматичній (імпліцитній) пам'яті у формі наскрізних фантомів - можливе лише послаблення ПТСР.

При зберіганні травматичної інформації лише в травматичній (імпліцитній) пам'яті у формі наскрізних фантомів - послаблення (усунення) ПТСР неможливе. Тому, що наскрізні фантоми не оптимізуються, $i$ тому, що спрацьовує алгоритм травматичної конверсії.

Ключові слова: травматична інформачія, фізіологія організму, психологічна травма, травматична пам'ять, автобіографічна пам'ять, посттравматичні стресові розлади, автоматизми психологічного захисту, травматичні латентні мегабіти, алгоритм травматичної конверсї̈, психологічний захист оптимізації, автоматизми оптимізаиії, архетипи оптимізації. 


\section{Psycho-physiological factors in transformation of traumatic information to post-traumatic stress disorder and psychological protection \\ Oleksandr O. Illiuk,}

senior lecturer of Social and Humanitarian disciplines

department in National academy of National Guard of Ukraine.

Relevance of a problem: Disappointing statistics of suicidal behavior and crime rates in veterans of Anti-Terrorist Operation in eastern Ukraine actualize Post-traumatic stress disorder (PTSD) transformation research.

Results. The methodological basis for describing the psychophysiological factors of the transformation of traumatic information in PTSD are philosophical provisions on the human psyche, the achievement of a systematic approach in psychology and physiology, modern empirical theories of consciousness, and more.

Conclusion. A psycho-traumatic event can cause psychologic trauma. Psychologic trauma physiologic manifestation is a development of psychophysiological neurotic disorders formation processes algorithm initiation and recreation program in internal physiologic processes regulation system. The mentioned psychophysiological formation is suggested to be denoted as "traumatic conversion algorithm". Traumatic conversion algorithm forms involuntarily under the influence of holistic traumatic event representation.

Traumatic conversion algorithm is an involuntarily formed and persisting in the physiologic regulation system program of consecutive neuropsychophysiologic processes initiation and recreation regarding negative information transformation into unpleasant experiences and Posttraumatic stress disorder.

Traumatic information optimization or its perception close to personal interests through optimization psychologic protection is the main route to relieve (eliminate) unpleasant experiences and PTSD.

Optimization automatisms and archetypes are the basis of optimization unconscious psychologic protection. Adaptation is the main way of optimization automatism formation.

Classification of information contained in psych unconscious sphere and capacity for optimization of individual kinds of this information is given.

PTSD relief (elimination) depends on means of traumatic information retention in memory. 
Іллюк О. Психофізіологічні фактори трансформації...

Complete elimination of PTSD is possible in cases of negative information retention solely in autobiographic memory in the form of traumatic latent megabits and crisis phantoms.

Only PTSD relief is possible in cases of simultaneous traumatic information retention both in autobiographic and traumatic (implicit) memory in the form of throughout phantoms.

PTSD relief (elimination) is not possible in cases of traumatic information retention exclusively in traumatic (implicit) memory in the form of throughout phantoms. The reasons for this are that throughout phantoms do not optimize and that traumatic conversion algorithm is engaging.

Keywords: traumatic information, body physiology, psychological trauma, traumatic memory, autobiographic memory, post-traumatic stress disorders, automatisms in psychological protection, traumatic latent megabits, scheme of traumatic conversion, psychological protection optimization, automatisms optimization, archatypes optimization.

Вступ. Світова статистика свідчить, що кожен п'ятий учасник бойових дій за відсутності будь-яких фізичних ушкоджень страждає нервово-психічними розладами, а серед поранених і калік - кожен третій. На території СНД вибіркові клінічні роботи визначають показник ПТСР серед ветеранів афганської війни у 30\%, і до 55\% у комбатантів (учасників бойових дій), які брали участь у локальних війнах останніх десятиліть (Підчасов, Ломакін, 2011).

За дослідженнями проведених в 1988 році, у 15,2\% американських ветеранів в'єтнамської війни спостерігалися виражені ПТСР, а ще у 11,1\% відзначалися окремі симптоми таких розладів. За іншими даними, приблизно у 25\% американських ветеранів В'єтнаму відзначається розвиток несприятливих особистісних змін після отриманої психотравми. До початку 1990-х рр.. близько 100000 ветеранів цієї війни покінчили життя самогубством, 40000 ведуть замкнутий, майже аутичний спосіб життя (Блінов, 2013).

Проблема ПТСР є актуальною і в Україні. Зараз ознаки ПТСР спостерігають у кожного четвертого учасника антитерористичної операції (Рон, 2019). Отримані ПТСР стать причиною суїцидів і жорстоких злочинів. За 4,5 роки війни на сході України від самогубств і вбивств загинуло 843 українських військових (Матіас, 2018). Важливо усвідомлювати, 
Вісник ХНПУ імені Г.С. Сковороди. Психологія. Випуск 62.

що в значної частини осіб, які пережили психотравмуючу подію, проблеми у сфері психічного здоров'я виникатимуть не одразу, а можуть з'явитися за якийсь час (Кокун та ін., 2017).

Саме тому, успішне вирішення цієї проблеми актуалізує потребу подальших наукових досліджень механізмів формування ПТСР та психологічного захисту для визначення ефективних напрямків роботи 3 попередження та подолання цього негативного явища.

Аналіз наукових досліджень і публікацій. У наукових виданнях опубліковано багато досліджень у яких вивчаються різні аспекти формування ПТСР. У більшості наукові праць розглядається сучасний стан у сфері дослідження ПТСР i напрямки психореабілітації постраждалих від воєнних психотравм (Гуменюк, Федчук, 2016), досліджуються організаційні підходи фахівців провідних країн світу щодо психологічного захисту від впливу бойового стресу (Блінов, 2017), визначаються основні причини та симптоми ПТСР (Ковальчук, 2011), узагальнюються історичні аспекти (Михальський, Царьов, 2011), умови формування та прояву ПТСР (Підчасов, Ломакін, 2011, Блінов, 2013, Гриб, 2019).

Аналіз наведених та інших публікацій свідчить, що вивчення зовнішніх чинників та проявів ПТСР мало поєднується 3 визначенням внутрішні $x$ механізми цього негативного явища, наприклад, в межах психологічного захисту. На сьогоднішній день, важливі аспекти ПТСР розглядаються в таких підходах до опису психологічного захисту як: психоаналітичного, психотерапевтичного, психофізіологічного, психологічного, філософського (Іллюк, 2018).

Але дослідження психологічного захисту недостатньо поєднуються $з$ вивченням травматичної пам'яті, яка $є$ важливою ланкою внутрішніх чинників ПТСР. Травматична пам'ять має ряд особливостей, що робить іiі відмінною від інших різновидностей цього психічного процесу. До однієї 3 них належить ускладненість процесу цілеспрямованого пригадування травматичних подій. Однак, у постраждалих часто і без затрати зусиль виникають мимовільні спогади пережитої ситуації. Зазвичай вони складаються 3 сенсорних вражень, 
відчуттів, емоцій. Поштовхом до початку пригадування можуть бути специфічні стимули, які віддаленим чином асоціюються 3 перенесеною травмою. Основною причиною цих особливостей $\epsilon$ спосіб кодування травматичних спогадів в пам'яті.

Більшість вчених сходяться на думці, що травматична подія кодується у вигляді імпліцитної пам'яті. Внаслідок цього не відбувається іiі інтеграція в автобіографічну, наративну пам'ять. Імпліцитна пам'ять зумовлює швидке, первинне сприйняття подій та генерування відповідних емоційних реакцій, поведінкових та тілесних станів. Згідно 3 поглядами П. Жане, травматичні спогади - це фрагменти сенсорних компонентів події, які відображаються у вигляді візуальних уявлень, нюхових, слухових, або кінестетичних відчуттів (Василюк, 2014).

Внутрішньою формою відображення, збереження та відтворення травматичної події (Засєкіна, 2012) є травматична інформація, яка при участі фізіологічних процесів організму трансформується в негативні переживання людини та ПТСР. Фізіологічною основою такої взаємодії і трансформації $є$ гормони, як результат фізіологічних та біохімічних процесів в організмі людини (Іллюк, 2019).

Отже, ПТСР є результатом дії великої кількості зовнішніх і внутрішніх чинників, які досліджуються фахівцями у різних сферах наукової i практичної діяльності. Тому $є$ нагальна потреба комплексного підходу дослідження психофізіологічних предикаторів трансформації травматичної інформації в ПТСР та психологічного захисту.

Мета статті. Дослідження психофізіологічних факторів трансформації травматичної інформації у посттравматичні стресові розлади та психологічного захисту.

Виклад основного матеріалу. Основною причиною суїцидальної та протиправної поведінки учасників бойових дій посадові особи та науковці визначають ПТСР, викликані спогадами про психічну травму спричинену травматичним стресовим впливом (Музичко, 2019).

Це визначення наводить на думку, що безпосереднім чинником ПТСР є травматична інформація, яка зберігається в 
Вісник ХНПУ імені Г.С. Сковороди. Психологія. Випуск 62.

несвідомій сфері психіки, а знання механізмів іiі формування, збереження і трансформації в негативні переживання та ПТСР позитивно впливатиме на подолання цього негативного явища. Дослідженню зазначених процесів сприяють фундаментальні філософські положення про психіку людини, бо “філософське” означає максимально універсальне, всеохоплююче, грунтовне, фундаментальне, суттєве (В. А. Канке), та досягнення системного підходу в психології і психофізіології.

Методологічною основою опису психофізіологічних процесів щодо формування (послаблення, усунення) ПТСР є філософські положення про сфери свідомості (свідому, несвідому, надсвідому), концепція системного підходу Б. Ф. Ломова в психології та теорія функціональних систем П. К. Анохіна. Особливе значення для дослідження природи цього явища мають розроблені Б. Ф. Ломовим принципи розгляду психічних явищ (різноплановості, багатомірності, багаторівневості, ієрархічності, системної детермінованості, розвитку) та рівні дослідження людини і її психіки (соціальний, психологічний, біологічний). Ідеї П. К. Анохіна про системоутворюючий компонент та групи пристосувальних результатів пояснюють закономірність появи нових психофізіологічних утворень під впливом змінених умов соціальної взаємодії (Кокун, 2020).

Методологічною основою розуміння співвідношення психіки і мозку (психічних i фізіологічних процесів) щодо трансформації травматичної інформації в ПТСР, є філософські положення про форми існування свідомості, а саме: раціональну (розумову), чуттєву (емоційну), «ейдетичну» (єдність раціонального і чуттєвого) та сучасні емпіричні теорії свідомості, такі як: теорія глобального робочого простору Б. Баарса; нейробіологічна теорія Ф. Кріка і К. Коха; теорія динамічного ядра Д. Тононі і Д. Едельмана; теорія таламокортікального зв'язку Р. Льїнаса; теорія рекурентної обробки В. Ламме та інші. Так, введена Б. Баарсом модель роботи «процесорів-експертів в мозку», що представляють собою складні нейронні мережі, та їх об'єднання в глобальний робочий простір, логічно пояснює процеси оброблення 
Іллюк О. Психофізіологічні фактори трансформації...

інформації, співвідношення механізмів усвідомлення відображених явищ навколишньої дійсності, переміщення інформації про них у сферу несвідомого та повернення у сферу свідомості (Ревонсуо, 2020).

Про те, що негативні фактори соціальної взаємодії впливають на фізіологію півкуль головного мозку i детермінують невротичні розлади доводить концепція пошукової активності В. Ротенберга та результати наукових досліджень Каттінга, В. Дегліна, Г. Аммона, М. Кляйна (Ротенберг, 2020).

Отже, наведене свідчить, що негативні фактори об'єктивної реальності через складні механізми психофізіологічної взаємодії можуть детермінувати негативні переживання та невротичні розлади. Але чому невротичні розлади руйнують життя людині і при відсутності зовнішніх стрес-чинників?

Справа в тому, що небезпечність й інтенсивність дії травматичної ситуації буває різною. В одних випадках небезпечна подія може бути чинником лише негативних переживань, а інша - детермінує психічні травми. На нашу думку, внутрішнім (фізіологічним) проявом (вираженням) психічної травми $є$ карбування (формування) в керуючій (регулюючій) системі внутрішніх фізіологічних процесів програми запуску і відтворення алгоритму психофізіологічних процесів формування невротичних розладів. При згадуванні травматичної ситуації програма запускає наведений алгоритм психофізіологічних процесів і відтворює невротичні розлади (ПТСР). Зазначене психофізіологічне утворення пропонується позначати категорією «алгоритм травматичної конверсії».

Сформованість, стійкість і дія (включення) алгоритму травматичної конверсії залежить від багатьох чинників, а саме: небезпечності й інтенсивності дії травматичної ситуації; способів зберігання травматичної інформації у несвідомій сфері психіки; видів та кількості фрагментів сенсорних компонентів небезпечної події, що зберігаються у травматичній пам'яті; особливостей внутрішніх нейрофізіологічних процесів; соціального оточення; особистісних якостей. 
Вісник ХНПУ імені Г.С. Сковороди. Психологія. Випуск 62.

Алгоритм травматичної конверсії - це мимовільно сформована і зафіксована в регулюючій системі фізіології організму програма запуску i відтворення послідовних нейропсихофізіологічних процесів щодо трансформації негативної інформації в неприємні переживання та посттравматичні стресові розлади.

Наведене свідчить, що основною ланкою логічного ланцюга психофізіологічних процесів 3 формування ПТСР $€$ травматична інформація. Алгоритм травматичної конверсії виконує роль лише каталізатора психофізіологічних процесів щодо трансформації травматичної інформації в ПТСР.

Саме тому основним напрямком (способом) пониження (усунення) негативних переживань і ПТСР $€$ оптимізація травматичної інформації, або іiі сприйняття, наближено до інтересів особистості, через застосування психологічного захисту оптимізації. У Вікіпедії поняття «оптимізація» (від англ. optimisation) тлумачиться як процес надання будь-чому найвигідніших характеристик, співвідношень. Під «інтересами» розуміються актуалізовані потреби соціальної взаємодії у різних сферах життєдіяльності. Тому інтереси можуть бути: ідеологічними, економічними, політичними, соціальнопсихологічними, правовими, етичними, естетичними, сімейними, службовими, безпековими, релігійними та ін. Психологічний захист оптимізацї - це сукупність мимовільних психічних процесів, свідомих способів розумової діяльності та практичних дій людини щодо збільшення відповідності суспільного буття їі інтересам, наслідком яких $є$ зменшення чи повне усунення неприємних переживань. Основними способами оптимізації невідповідності предметів і явищ об'єктивної реальності інтересам людини є: задоволення потреб та інтересів; усунення (подолання) джерела невідповідності (загрози); коригування потреб та інтересів; подолання емоційного збудження (неприємних переживань); витіснення; заперечення реальності; деперсоналізація; раціоналізація; проекція; ідентифікація; компенсація; сублімація; регресія; обман; маніпуляція; агресія та багато інших. 
Іллюк О. Психофізіологічні фактори трансформації...

Психологічний захист оптимізації відповідно до сфер психіки людини класифіковано як, свідомий психологічний захист оптимізації, несвідомий психологічний захист оптимізації і надсвідомий психологічний захист оптимізації. Свідомий психологічний захист оптимізації може здійснювати як сама людина так і сторонні особи. Визначення зазначених категорій наведено у попередніх дослідженнях (Іллюк, 2016).

Слід зазначити, що проблеми емоційної регуляції досліджуються в рамках різних психологічних систем і підходів, наприклад, «копінг-стратегій». У науковців, закономірно, виникає питання, що $є$ спільного між категорією «копінгстратегії» (Рассказова, 2020) i, наприклад, категорією «свідомий психологічний захист оптимізації» та в чому полягають відмінності? На нашу думку, спільним $є$ їх системоутворюючий компонент (згідно П. К. Анохіна) - це результат, а саме попередження, пониження чи усунення неприємних переживань. Головна їх відмінність полягає в тому, що перша категорія передбачає як свідомі так і довільні дії, а друге - лише свідомі. У співвідношенні цих категорій визначальним $є$ те, що «копінг-стратегії» (свідомої дії) у межах «свідомого психологічного захисту оптимізації» виконують роль лише способів оптимізації. У «системі психологічного захисту» (філософський підхід) мимовільні процеси розглядаються на рівні «несвідомого психологічного захисту оптимізації», де копінг-стратегії (несвідомої дії) також виконують роль лише способів оптимізації (як і захисні механізми).

В основі несвідомого психологічного захисту оптимізації є автоматизми психологічного захисту. Автоматизми психологічного захисту - це сукупність свідомо і мимовільно сформованих на рівні особистісного і колективного несвідомого несвідомої сфери психіки психофізіологічних утворень для захисту свідомості від руйнівної дії неприємних переживань, через оптимізацію травматичної інформації про неприємну (загрозливу) взаємодію з об'єктивною реальністю, наближено до інтересів особистості. Автоматизми психологічного захисту спрацьовують мимовільно і класифікуються відповідно до 
Вісник ХНПУ імені Г.С. Сковороди. Психологія. Випуск 62.

глибинних рівнів несвідомої сфери психіки, як: автоматизми оптимізації та архетипи оптимізації.

На рівні особистісного несвідомого несвідомої сфери психіки (відкритого 3. Фрейдом), що відноситься до особистого досвіду людини, формуються автоматизми оптимізації. Автоматизми оптимізації - це зразки (приклади) оптимізації виявленої невідповідності об'єктивної реальності інтересам особистості та стереотипи різноманітних варіантів попередньої оптимізації, які мимовільно витіснені у підсвідомість особистісного несвідомого несвідомої сфери психіки людини. Основним способом формування автоматизмів оптимізації $\epsilon$ адаптація, тому, що автоматизми оптимізації є психічними утвореннями, а адаптація $\epsilon$ лише процесом щодо їх формування.

На рівні колективного несвідомого несвідомої сфери психіки (відкритого К. Юнгом) знаходяться архетипи оптимізації, які сформовані досвідом попередніх поколінь і лише успадковуються людиною. Архетипи оптимізації - це комплекс мимовільних процесів у сфері колективного несвідомого несвідомої сфери психіки людини щодо зміни виявленої невідповідності об'єктивної реальності їі інтересам із забезпечення життєдіяльності, попередження, зниження або усунення негативних переживань До архетипів оптимізації можна віднести такі захисні механізми психіки як: витіснення, заперечення, деперсоналізація, раціоналізація, проекція, ідентифікація, компенсація, сублімація, регресія та ін. Архетипи оптимізації - це лише один із багатьох можливих видів прообразів-архетипів колективного несвідомого несвідомої сфери психіки (Іллюк, 2016).

Генезис ПТСР та можливість їх послаблення (усунення) залежить від трьох груп факторів: особливостей інформації, в якій відображена травматична подія; сформованості, стійкості і дії (включення) алгоритму травматичної конверсії; способів зберігання травматичної інформації в пам'яті людини.

Інформація про травматичні події зберігається на рівні особистісного та колективного несвідомого несвідомої сфери психіки. За способами формування така інформація поділяється на: 1) автоматизми, 2) латентні мегабіти, 3) кризисні фантоми, 
4) наскрізні фантоми, 5) гібридні фантоми. Причому перші чотири види зберігаються в особистісному несвідомому несвідомої сфери психіки і відносяться до особистого досвіду людей, а останній - в колективному несвідомому несвідомої сфери психіки і до їх особистого досвіду не має відношення. Важливою особливістю цих видів інформації $\epsilon$ здатність до оптимізації. А саме: піддаються оптимізації - латентні мегабіти; оптимізуються після застосування психоаналітичного методу кризисні фантоми; не піддаються оптимізації - наскрізні фантоми та гібридні фантоми. Чинником ПТСР в учасників бойових дій, зазвичай, $\epsilon$ лише ті види інформації, що відноситься до їх особистого досвіду. Наведемо визначення зазначених видів інформації.

1. Автоматизми - інформація про психічні явища, яка спочатку контролювалася свідомістю, а потім у результаті тривалого тренування й багаторазового повторення набула несвідомого характеру і зберігається в особливому шарі несвідомої сфери психіки - підсвідомості.

2. Латентні мегабіти - інформація, що попередньо була у свідомості, але $\epsilon$ такою, про яку забули чи свідомо витіснили в особистісне несвідоме несвідомої сфери психіки.

3. Кризисні фантоми - інформація про обставини, явища, предмети та особисті переживання 3 приводу небезпечної для життєдіяльності людини події (ситуації), яка була мимовільно витіснена зі свідомості до особистісного несвідомого несвідомої сфери психіки.

4. Наскризні фантоми - інформація, що потрапила до особистісного несвідомого несвідомої сфери психіки без усвідомлення іiі людиною в результаті психоаналітичного, нейролінгвістичного, парапсихологічного, екстрасенсорного впливів тощо.

5. Гібридні фантоми - інформація, що перебуває у колективному несвідомому несвідомої сфери психіки, яка, можливо, детермінована генотипом людини та космічним інформаційно-змістовним полем і $€$ відображенням досвіду попередніх поколінь (Іллюк, 2016). 
Вісник ХНПУ імені Г.С. Сковороди. Психологія. Випуск 62.

У життєдіяльності військовослужбовців всі наведені види інформації можуть бути чинниками негативних переживань. Але беручи до уваги те, що наскрізні і гібридні фантоми не оптимізуються, а кризисні фантоми підлягають оптимізації лише після втручання психоаналітика, то особливу увагу слід приділити латентним мегабітам.

Латентні мегабіти можуть бути наступних видів: 2.1 нейтральні; 2.2 гедоністичні; 2.3 травматичні. Беручи до уваги способи усвідомлення (пригадування) травматичних подій травматичні латентні мегабіти можна класифікувати на такі, як: 2.3.1 фантомні; 2.3.2 перманентні; 2.3.3 нав'язливі; 2.3.4 поточні. Визначення зазначених категорій наведено у попередніх дослідженнях (Іллюк, 2019).

Слід зауважити, що наскрізні (гібридні) фантоми також можна класифікувати на: 4.1 (5.1) нейтральні; 4.2 (5.2) гедоністичні; 3.3 (5.3) травматичні.

Але чому при згадуванні одних травматичних подій невротичні реакції «оживають», а при згадуванні інших вони відсутні? Чому в одних випадках заходи психологічного захисту невротичні розлади послаблюють або усувають, а в інших проблеми залишаються незмінними?

Для пояснення цього феномену пропонується концепиія сенсорно-наративного зберігання травматичної інформації. На нашу думку причина в тому, що інформація про небезпечну подію зберігається не цілісно, а одночасно в різних видах пам'яті. Так деякі фактори небезпечної події зберігаються в автобіографічній пам'яті у формі вербалізованих (словесно виражених), отже й усвідомлених логіко-понятійних компонентах, а деякі можуть зберігатись у травматичній пам'яті як фрагменти сенсорних компонентів події, що відображаються у вигляді візуальних уявлень, нюхових, слухових, або кінестетичних відчуттів. Їх кодування у вигляді імпліцитної (неявної, схованої) пам'яті, без усвідомлення предмета запам'ятовування, перешкоджає інтеграції в автобіографічну, наративну пам'ять і приєднання до загального фонду знань особистості (Василюк, 2014). 
Іллюк О. Психофізіологічні фактори трансформації...

Оптимізація усвідомленої інформації про небезпечну подію у формі логіко-понятійних компонентах (травматичних латентних мегабітів), не завжди усуває негативні переживання та ПТСР, саме тому, що у несвідомій сфері психіки можуть залишатись фрагменти інформації тієї ж події у травматичній (імпліцитній) пам'яті у формі сенсорних компонентів події (травматичних наскрізних фантомів). Які, не піддаючись мимовільній і свідомій оптимізації, детермінують негативні переживання та ПТСР в результаті спрацювання алгоритму травматичної конверсії.

Причина такої вибірковості в тому, що алгоритм травматичної конверсії формується мимовільно під впливом цілісного відображення небезпечної події. А інформація про небезпечну (загрозливу) подію може одночасно зберігатись як в автобіографічній (наративній) пам'яті, у формі травматичних латентних мегабітів, так і в травматичній (імпліцитній) пам'яті, у формі травматичних наскрізних фантомів.

При оптимізації травматичних латентних мегабітів неприємні переживання і ПТСР лише послаблюються. Бо навіть випадкова взаємодія 3 якимись сенсорними компонентами цієї небезпечної події негативну дію травматичних наскрізних фантомів реанімує. Вони мимовільно, через сформований алгоритм травматичної конверсії, неприємні переживання та ПТСР відновлюють. Їх небезпечність, ймовірно, залежить від кількості та інтенсивності сенсорних компонентів події, що наповнили зміст наскрізних фантомів та інше.

Якщо ж інформація про небезпечну (загрозливу, неприємну) подію зберігається лише в автобіографічній (наративній) пам'яті, у формі травматичних латентних мегабітів або кризисних фантомів, то ПТСР, детерміновані цією небезпечною подією, можна усунути повністю, оптимізуючи травматичні латентні мегабіти або їх сприйняття наближено до інтересів особистості. Оптимізація травматичної інформації у формі кризисних фантомів можлива лише після застосування психоаналітичного методу.

Не можна ні послабити, ні усунути негативні переживання та ПТСР, якщо інформація про небезпечну подію 
Вісник ХНПУ імені Г.С. Сковороди. Психологія. Випуск 62.

зберігається лише в травматичній (імпліцитній) пам'яті у формі травматичних наскрізних фантомів. По-перше, тому, що травматичні наскрізні фантоми не оптимізуються, i, по-друге, тому, що спрацьовує алгоритм травматичної конверсії.

\section{Висновки.}

1. Методологічною основою опису психофізіологічних факторів трансформації травматичної інформації в ПТСР $\epsilon$ філософські положення про психіку людини, досягнення системного підходу в психології і фізіології, сучасні емпіричні теорії свідомості та інше.

2. При визначенні причин ПТСР до уваги слід брати особливості інформації в несвідомій сфері психіки, а саме: автоматизмів, латентних мегабітів, кризисних фантомів, наскрізних фантомів, гібридних фантомів.

3. Психологічний захист оптимізації травматичної інформації класифікується як, свідомий психологічний захист оптимізації, несвідомий психологічний захист оптимізації та надсвідомий психологічний захист оптимізації.

4. Внутрішнім проявом (вираженням) психічної травми $€$ сформована в керуючій (регулюючій) системі фізіологічних процесів програма запуску i відтворення ПТСР у формі алгоритму травматичної конверсії.

5. Ефективність психологічного захисту оптимізації залежить від способів зберігання травматичної інформації у пам'яті людини, а саме: в автобіографічній пам'яті i травматичній пам'яті; лише в автобіографічній пам'яті; лише в травматичній пам'яті. Перманентним чинником ПТСР $€$ травматична інформація, що зберігається в травматичній пам'яті.

6. Автоматизми психологічного захисту класифікуються на: автоматизми оптимізації (в особистісному несвідомому) і архетипи оптимізації (в колективному несвідомому). Основним способом формування автоматизмів оптимізації є адаптація.

7. Алгоритм травматичної конверсії, як форма внутрішнього вираження психологічної травми, $є$ перманентним каталізатором психофізіологічних процесів трансформації травматичної інформації в ПТСР. 
Іллюк О. Психофізіологічні фактори трансформації...

Перспективи подальших досліджень. Подальше опрацювання цієї теми доцільно спрямувати на дослідження психологічного захисту оптимізації щодо попередження, пониження та усунення ПТСР.

\section{Література}

Блінов О. А. (2013). Прояви посттравматичних стресових розладів. Актуальні проблеми психологіï. Т. 7. Вип. 32. С. 15-20. URL: http://appsychology.org.ua/data/jrn/v7/i32/4.pdf (дата звернення 15.01.2019).

Блінов О. А. (2017). Психологічний захист від бойового стресу в збройних силах провідних країн світу. Проблеми сучасної психології. Вип. 38. С. 38-52. URL: http://nbuv.gov.ua/UJRN/Pspl_2017_38_6 (дата звернення 10.03.2019).

Василюк О. П. (2014). Теоретико-методологічний аналіз поняття «травматична пам'ять» 3 позиції когнітивного підходу. Вісник Харківського національного педагогічного університету імені Г. С. Сковороди. $\quad$ Вип. $48 . \quad$ С. 29-36. URL: http://nbuv.gov.ua/UJRN/VKhnpu_psykhol_2014_48_6 (дата звернення 11.04.2019).

Гриб А. С. (2019). Посттравматичний стресовий розлад у військовослужбовців - учасників бойових дій. Науковий журнал «Психологія». URL: http://medpsyhology.pp.ua/посттравматичнийстресовий-розлад-у (дата звернення 15.01.2019).

Гуменюк Л. Й., Федчук О.В. Дослідження посттравматичного стресового розладу і напрямків психореабілітації постраждалих від воєнних психотравм. Науковий віник Львівського державного університету внутрішніх справ. 2016. № 1. С. 228-240. URL. http://www2.lvduvs.edu.ua/documents_pdf/visnyky/nvsp/01_2016/16glivvp .pdf (дата звернення 19.11.2018).

Засєкіна Л.В.Психолінгвістична реорганізація травматичної пам'яті 3 перспективи психічного здоров'я особистості. Вісник Національної академії Державної прикордонної служби України. 2012. Вип. 1. URL: http://nbuv.gov.ua/UJRN/Vnadps_2012_1_32 (дата звернення 19.12.2018).

Іллюк О. О. Зміст та застосування підходів до опису психологічного захисту особового складу. Честь і закон. 2018. № 1. C. 120-127. URL: http://nbuv.gov.ua/UJRN/Chiz_2018_1_19 (дата звернення 11.04.2019). 
Вісник ХНПУ імені Г.С. Сковороди. Психологія. Випуск 62.

Іллюк О. О. Інформація і фізіологія організму як основні чинники посттравматичних стресових розладів та психологічного захисту. Науковий вісник Льотної академії. Серія: Педагогічні науки. 2019. - - Вип. 6. - 6 С. 67-74. URL: http://nbuv.gov.ua/UJRN/sbfasps_2019_6_11 (Дата звернення 21.11.2019).

Іллюк О. О. Структура системи психологічного захисту особового складу. Честь і закон. 2016. № 2. С. 58-66. URL: http://nbuv.gov.ua/UJRN/Chiz_2016_2_10 (дата звернення 11.04.2019).

Ковальчук В. М. Посттравматичний стресовий розлад, як наслідок дизадаптивного прояву стресогенного впливу. Вісник Національного університету оборони України. 2011. Вип. 4 (23). С. 152-155.

Кокун О. М. Психофізіологія. Навчальний посібник. URL: http://lib.iitta.gov.ua/1608/1/Кокун_Психофізіологія.pdf (дата звернення 15.01.2020).

Кокун О. М., Агаєв Н. А., $\quad$ Пішко I. О., Остапчук В. В. (2017). Психологічна робота з військовослужбовцями учасниками АТО на етапі відновлення: методичн. посіб. К.: НДЦ ГП ЗСУ, 2017. $282 \mathrm{c}$. URL.

Матіас А. В. Про психічне здоров'я військових. Цензор.НЕТ. https://censor.net.ua/news/3090132/s_nachala_voyiny_zafiksirovany_843_s luchaya_smerteyi_ukrainskih_voennyh_ot_samoubiyistv_i_ubiyistv_matios (дата звернення 19.11.2018).

Михальський А. В., Царьов Ю. О. Посттравматичний стресовий розлад: історичний огляд. Збірник наукових праць К-ПНУ імені Івана Огієнка, Інституту психології ім. Г. С.Костюка НАПН України. Проблеми сучасної психології. 2011. Вип. 12. С. 687-696.

Музичко Л. Т. Психокорекційна допомога молоді 3 посттравматичними порушеннями інтелектуальної та емоційновольової сфери. Дис... канд. психолог. наук. URL: https://new.npu.edu.ua/images/file/vidil_aspirant/dicer/\%D0\%94_26.053.23 /MUZYCHKO.pdf (Дата звернення 17.10.2019).

Підчасов Є. В., Ломакін Г. І. (2011). Аналіз соціальнопсихологічних проявів ПТСР в осіб, які приймали участь у бойових діях. Проблеми екстремальної та кризової психології. 2011. Вип. 10 C. 86-98.

Рассказова Е. И., Гордеева Т. О. Копинг-стратегии в психологии стресса: подходы, методы и перспективы исследований. URL: 
http://psystudy.ru/index.php/num/2011n3-17/493-rasskazovagordeeva17.html (дата обращения 31.01.2020).

Ревонсуо А. Психология сознания / Перевод: А. Стативка, 3. С. Замчук.

URL: http://sncps.ru/data/documents/Revonsuo_A._Psihologiya_Soznaniya.a4.pd $\mathrm{f}$ (дата звернення 15.01.2020).

Роп Н. Один із 93\%: чи несуть ветерани «загрозу». URL: https://www.mediaport.ua/odin-iz-93-chi-nesut-veterani-zagrozu (дата звернення 17.12.2019).

Ротенберг В. С. «Образ я» и поведение. URL: http://www.vsrotenberg.rjews.com/obraz-ya-i-povedenie.pdf (дата обращения 26.01.2020).

Оригінальний рукопис отриманий 16 грудня 2019 року

Стаття прийнята до друку 28 січня 2020 року 